\title{
Pertumbuhan Api-Api (Avicennia alba) dan Kelimpahan Epifauna Bentik di Kawasan Rehabilitasi Mangrove Desa Kedaburapat Kabupaten Kepulauan Meranti
}

\author{
Efriyeldi $^{*}$, Aras Mulyadi ${ }^{2}$, Joko Samiaji $i^{3}$ \\ ${ }^{1,2,3}$ Dosen Fakultas Perikanan dan Kelautan Universitas Riau \\ *Koresponden E-mail: efriyeldiedi@gmail.com
}

(Diterima 16 Maret 2021 | Disetujui 28 Mei 2021 | Diterbitkan 18 Juli 2021)

\begin{abstract}
The research was conducted in July - October 2020. Collection of data A. alba growth and abundance of benthic epifauna was carried out in the mangrove rehabilitated area of Kedabupat village, Kepulauan Meranti Regency. The aims of this study was to analyze the growth (stems height and diameter) of the mangrove A. alba species as a result of rehabilitation and abundance of benthic epifauna in the area. The method used in this research was a survey method, where data was obtained by directly to the research location. The data collected was data on the height and diameter of A. alba stems, density of macro epifauna species, and water quality in the field, then followed by analysis of water and sediment samples in the laborato$r y$. The results showed that the average increace in height of the stem by zone was $6.45-12.93 \mathrm{~cm} / \mathrm{month}$, meanwhile the average value of the increase in stem diameter by zone is $1.53-1.85 \mathrm{~mm} / \mathrm{month}$. There were 13 epifauna benthic species from 2 classes namely Gastropod and Malacostraca from mangrove rehabilitation. Gastropod class that was Littoraria melanostoma, Nerita balteata and Sphaerassiminea miniata; from the malacostraca class that was Uca coarctata, Metopograpsus latifrons, Ceonobita cavipes, and Clibanarius longitarsus. Benthic epifauna abundance values average ranged from 31.33-52.22 ind/m2.
\end{abstract}

Keywords: Avicennia alba, Diameter, Epifauna benthic, Height, Kedaburapat village, Rehabilitation

\section{PENDAHULUAN}

Mangrove merupakan ekosistem utama yang terdapat di wilayah pesisir selain ekosistem terumbu karang (coral reef) dan ekosistem lamun (seagrass). Ekosistem mangrove ini memiliki fungsi yang dapat dikelompokkan atas fungsi ekologis dan ekonomis. Bengen (2002) menyatakan bahwa secara ekologis ekosistem mangrove berperan dalam menjamin tterjaganya lingkungan fisik dari gempuran ombak, terjangan angin, serta merupakan habitan dan tempat pemijahan oleh berbagai jenis biota laut, seperti ikan, udang, kepiting, kerang, siput dan hewan jenis lain. Selanjutnya menurut Kusmana, Onrizal \& Sudarmaji (2003) bahwa ekosistem mangrove ini mempunyai fungsi sebagai sumber makanan, tempat berlindung, berkembang biak atau tempat pembesaran bagi berbagai biota laut.

Mangrove adalah komunitas vegetasi pantai di daerah tropis dan sub tropis yang didominasi oleh beberapa jenis pohon yang mampu tumbuh dan berkembang baik pada daerah pasang surut pantai berlumpur. Ekosistem mangrove di Indonesia memiliki keanekaragaman jenis vegetasi yang tinggi. Jenis vegetasi mangrove tercatat adalah sebanyak 202 jenis yang terdiri atas 89 pohon, 5 jenis palem, 19 jenis liana, 44 jenis epifit, dan 1 jenis sikas. Namun demikian hanya terdapat sekitar 47 jenis vegetasi yang spesifik hutan mangrove. Setidaknya di dalam hutan mangrove terdapat salah satu jenis tumbuhan mangrove sejati yang termasuk ke dalam empat family yaitu Rhizophoraceae (Rhizophora, Bruguiera, dan Ceriops), Avicenniaceae (Avicennia), Sonneraticeae (Sonneratia), dan Meliaceae (Xylocarpus) (Bengen, 2002).

Saat ini hutan mangrove banyak memperoleh ancaman dari berbagai faktor, baik faktor alam, maupun faktor manusia yang berakibat terjadinya abrasi pantai. Banyak wilayah pesisir yang mengalami abrasi karena hantaman gelombang laut, terutama pada musim-musim angin tertentu, termasuk di Provinsi Riau. Salah satu wilayah pesisir yang mengalami abrasi yang relatif parah di Provinsi Riau adalah di pesisir timur Pulau Rangsang Kabupaten Kepulauan Meranti, tepatnya Desa Kedaburapat yang berhadapan langsung dengan Selat Malaka. Berdasarkan pengamatan di lapangan dan komunikasi pribadi dengan kepada desa setempat sudah puluhan meter lahan yang telah menjadi laut dalam rentang waktu 10 tahun terakhir ini di Desa Kedaburapat ini.

Selain dapat mengurangi terjadinya abrasi pantai, keberadaan ekosistem mangrove juga dapat meningkatkan ketersedian sumberdaya perikanan di perairan tersebut. Hal ini dikarenakan peranan biologi ekosistem mangrove. Keberadaan ekosistem mangrove dapat meningkatkan hasil tangkapan nelayan dan ketersediaan sumberdaya perikanan sebagai sumber protein masyarakat. 
Untuk mengatasi ancaman gelombang yang berlangsung terus menerus tersebut telah dilakukan rehabilitasi. Upaya rehabilitasi hutan mangrove ini sering kali mengalami kegagalan, yang diakibatkan berbagai faktor, seperti jenis yang ditanam tidak sesuai, waktu penanaman yang tidak tepat, tidak dirawat dan sebagainya. Rehabiltasi mangrove yang ada di Desa Kedaburapat merupakan salah satu dari sedikit kegiatan rehabilitasi mangrove yang tergolong berhasil, walaupun dalam luasan relatif kecil, yaitu sekitar 3 (tiga) ha. Kegiatan rehabilitasi ini dilakukan Dinas Kelautan dan Perikanan Provinsi Riau yang melibatkan Dosen Universitas Riau. Pesisir pantai Desa Kedaburapat yang terabrasi ini sudah ditanami mangrove jenis api-api (Avicennia sp) pada tahun 2017 dan 2018 oleh Dinas Kelautan dan Perikanan Provinsi Riau. Pada tahun 2019 dilakukan penanaman oleh Dinas Lingkungan Hidup dan Kehutana Provinsi Riau di sebelahnya. Mangrove yang ditanam tersebut tumbuh dengan baik, terutama yang ditanam pada tahun 2018 dan 2019. Pada kawasan tersebut telah menjadi habitat bagi berbagai epifauna bentik seperti moluska.

Walaupun pertumbuhan api-api yang ditanam tumbuh dengan baik, namun belum data mengenai pertumbuhannya. Selain itu data epifauna bentik apa saja yang telah hadir setelah adanya api-api juga belum ada. Informasi kecepatan pertumbuhan api-api muda hasil penanaman dan kehadiran biota menjadi penting untuk diketahui. Maka dari itu diperlukan kajian tentang kecepatan pertumbuhan mangrove apiapi yang ditanam dan keragaman biota yang berasosiasi di mangrove hasil rehabilitasi ini.

Tujuan penelitian ini adalah untuk menganalisis pertumbuhan api-api (Avicennia alba) hasil penanaman dan kelimpahan epifauna bentik yang berasosiasi di kawasan rehabilitasi mangrove Desa Kedaburapat Kecamatan Rangsang Pesisir Kabupaten Kepulauan Meranti Provinsi Riau yang berada di belakang pemecah gelombang.

\section{BAHAN DAN METODE}

Penelitian ini dilakukan pada bulan Juli sampai Oktober 2020. Pengamatan dan pengumpulan data pertumbuhan $A$. alba dan kelimpahan epifauna yang berasosiasi dilakukan di kawasan rehabilitasi mangrove Desa Kedaburapat Kecamatan Rangsang Pesisir Kabupaten Kepulauan Meranti hasil penanaman pada tahun 2019 atau umur \pm 1 tahun setelah ditanam (Gambar 1). Analisis fraksi sedimen, kandungan nitrat dan fosfat pada sedimen dan air dilakukan di Laboratorium Kimia Laut, sedangkan epifauna bentik diidentifikasi di Laboratorium Biologi Laut Jurusan Ilmu Kelautan Fakultas Perikanan dan Kelautan Universitas Riau.

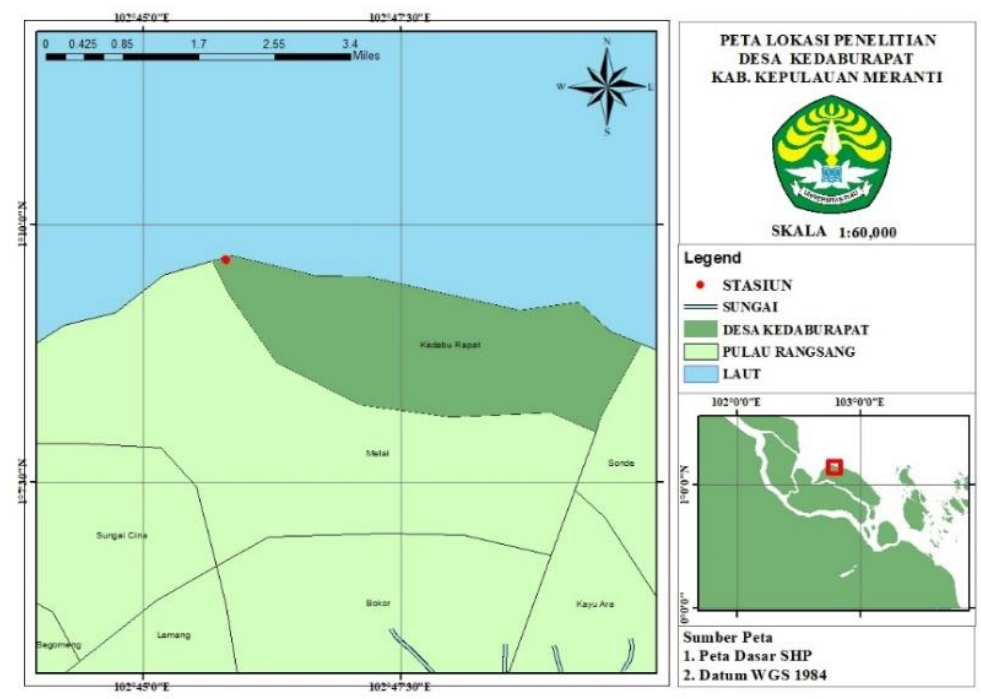

Gambar 1. Lokasi Penelitian di Desa Kedaburapat

Penelitian ini dilaksanakan menggunakan metode survey. Data dikumpulkan melalui turun langsung ke lokasi penelitian dan analisis laboratorium. Data pertumbuhan anakan $A$. alba yang diukur meliputi tinggi dan diameter batang yang sudah ditanam pada tahun 2019 atau satu tahun penanaman yang mempunyai jarak tanam $1 \mathrm{~m} \times 1 \mathrm{~m}$. Epifauna bentik dikumpulkan pada kawasan yang sama.
Titik pengambilan sampel ditetapkan secara purposive, yaitu dengan menempatkan tiga transek dalam kawasan rehabilitasi tersebut. Pada setiap transek ditempatkan tiga buah plot ukuran $5 \mathrm{~m} \times 5 \mathrm{~m}$ yang mewakili zona bagian darat (upper), zona tengah (middle) dan zona arah ke laut (lower) yang berhadapan dengan batu bronjong (pemecah gelombang) sebagai tempat pengambilan, pengamatan dan pengukuran sampel yang diperlukan, baik 
pengukuran tinggi dan diameter batang anakan $A$. alba maupun pengumpulan epifauna bentik.

Jumlah pohon yang diukur tinggi dan diamater batangnya pada setiap plot adalah adalah 5 pohon. Pertambahan tinggi pohon dan diameter batang dinyatakan sebagai selisih tinggi $(\mathrm{cm})$ dan diameter batang $(\mathrm{mm})$ dalam periode waktu tertentu yang telah ditetapkan, yang pada penelitian ini dalam waktu tiga bulan. Pengukuran dilakukan setiap satu bulan selama tiga bulan pengamatan. Diameter batang diukur pada ketinggian $20 \mathrm{~cm}$ dari permukaan tanah, sedangkan untuk mengukur tinggi pohon dilakukan dengan pengukuran dimulai dari pangkal batang yang timbul di permukaan tanah (Gambar 2) hingga ujung atau pucuk pohon.

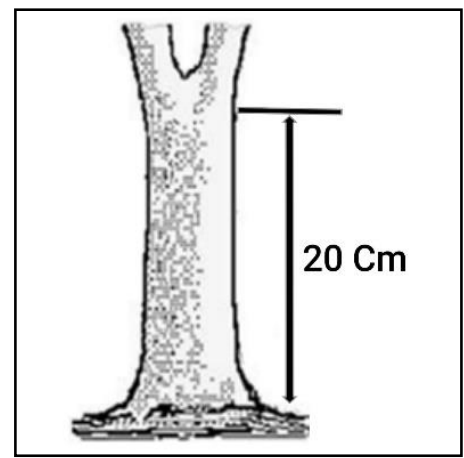

Gambar 2. Pengukuran Diameter Batang A. alba Rumus pertumbuhan diameter pohon diperoleh menurut Susila (2010):

$$
\begin{array}{ll}
\mathrm{D} & =(\mathrm{Dt}-\mathrm{Da}) / \mathrm{T} \\
\mathrm{Dt} & =\text { Diameter pohon di akhir penelitian }(\mathrm{mm}) \\
\mathrm{Da} & =\text { Diameter pohon di awal penelitian }(\mathrm{mm}) \\
\mathrm{T} & \quad=\text { Jarak waktu pengukuran (bulan) }
\end{array}
$$

Rumus pertumbuhan tinggi pohon diperoleh berdasarkan rumus Susila (2010):

$\mathrm{T}=(\mathrm{Tt}-\mathrm{Ta}) / \mathrm{T}^{\prime}$

$\mathrm{Tt}=$ Diameter pohon di akhir penelitian $(\mathrm{mm})$

$\mathrm{Ta}=$ Diameter pohon di awal penelitian $(\mathrm{mm})$

T' = Jarak waktu pengukuran (bulan)

Sampel epifauna bentik dan sedimen dikumpulkan pada sub-plot berukuran $1 \mathrm{~m} \times 1 \mathrm{~m}$ secara acak sebanyak tiga buah. Pengambilan sampel sedimen dengan bantuan pipa paralon diameter 10 $\mathrm{cm}$ dengan cara membenamkannya ke substrat dasar hingga kedalaman $10 \mathrm{~cm}$ pada setiap plot. Sampel sedimen diambil sebanyak 300 gram, kemudian dimasukkan ke dalam kantong plastik yang sudah dilabeli. Sampel sedimen kemudian dianalisis di laboratorium untuk mengetahui tipe sedimen dan kandungan zat hara (nitrat dan fosfat). Sampel epifauna bentik dikumpulkan dengan cara memungutnya dengan bantuan sekop pada tiga buah sub-plot dengan ukuran $1 \mathrm{~m} \times 1 \mathrm{~m}$. Sampel yang diperoleh selanjutnya dimasukkan ke dalam kantong plastik yang sudah diberi label dan ditambahkan larutan formalin $10 \%$ sebagai pengawet. Epifauna bentik yang diperoleh diidentifikasi di laboratorium dengan merujuk kepada buku Morton (1990) \& Susetiono (2005).

Pada kawasan rehabilitasi mangrove tersebut diukur kualitas perairan yang meliputi suhu, salinitas dan $\mathrm{pH}$ serta dilakukan pengambilan sampel air dan sedimen. Parameter kualitas perairan diukur secara langsung di lapangan pada setiap transek di dalam kawasan rehabilitasi mangrove Desa Kedaburapat Kabupaten Kepulauan Meranti dengan tiga kali pengulangan pada waktu air laut pasang. Analisis sampel yang dilakukan di laboratorium meliputi kandungan nitrat sedimen dan air menggunakan metode Brucine Sulfat, kandungan fosfat pada sedimen dan air menggunakan spektofotometer dengan panjang gelombang $543 \mathrm{~nm}$. Analisis fraksi sedimen menggunakan 2 metode, yaitu metode pengayakan basah dan metode pipet. Metode pengayakan bertingkat untuk mendapatkan $\varnothing-1-\varnothing 7$, sementara untuk metode pipet digunakan pipet volumetrik untuk mendapatkan Ø5-Ø7. Selanjutnya tipe sedimen ditentukan menggunakan segitiga Shepard.

Data pertumbuhan api-api, jenis dan kelimpahan epifauna bentik, bahan organik subtrat dasar, nitrat dan fosfat pada air dan sedimen serta kualitas perairan yang diperoleh selanjutnya ditabulasikan dan dianalisis secara deskriptif. Uji Anova digunakan untuk mengetahui perbedaan pertumbuhan tinggi dan diameter anakan api-api serta kelimpahan epifauna bentik antar zona dan selanjutnya dibahas secara deskriptif.

\section{HASIL DAN PEMBAHASAN}

\section{Keadaan Umum Daerah Penelitian}

Desa Kedaburapat merupakan salah satu desa di Pulau Rangsang Kabupaten Meranti Provinsi Riau. Desa ini berhadapan langsung dengan Selat Malaka sehingga mendapat ancaman abrasi yang sangat tinggi. Upaya yang telah dilakukan untuk menanggulangi ancaman abrasi di pesisir Desa Kedaburapat adalah membangun kontruksi pemecah gelombang (batu bronjong) yang berada sekitar $230 \mathrm{~m}$ dari garis pantai yang ada saat ini pada tahun 2014. Pemecah gelombang tersebut mempunyai lebar 8 meter bagian bawah dan 2,5 meter bagian atas.

Secara geografis kawasan rehabilitasi hutan mangrove Desa Kedaburapat berada pada koordinat $1^{\circ} 9^{\prime} 33,11^{\prime \prime} \mathrm{LU}$ dan $102^{\circ} 46^{\prime} 8,38^{\prime \prime}$ BT. Kegiatan penanaman mangrove di Desa Kedaburapat telah dilakukan sejak tahun 2014, namun penanaman yang berhasil baru yang dilakukan tahun 2017, 2018 dan 2019 dengan jarak tanaam 1 meter setelah dilakukan pemasangan pemecah gelombang dan terbentuk hamparan lumpur. Penanaman mangrove dilakukan oleh POKMASWAS Karya Pesisir dengan bantuan dana dari DKP Provinsi Riau dan DLHK Provinsi Riau. Keberadaan pemecah gelombang tidak saja memberi manfaat terjaganya pantai dari gelombang 
tapi juga menjadi tempat penambatan kapal-kapal nelayan pada tiang-tiang jembatan yang dibuat pihak Desa Kedaburapat. Jembatan yang dibangun sepanjang lebih kurang 230 m yang disertai adanya pondok-pondok untuk santai juga telah menjadi tempat wisata yang tidak saja dikunjungi warga sekitar tapi juga desa tetangga.

\section{Parameter Lingkungan}

Hasil pengukuran parameter kualitas perairan di kawasan rehablitasi mangrove dapat dilihat pada Tabel 1.

Tabel 1. Hasil rata-rata pengukuran parameter kualitas perairan

\begin{tabular}{llll}
\hline Parameter & Transek 1 & Transek 2 & Transek 3 \\
\hline Suhu $\left({ }^{\circ} \mathrm{C}\right)$ & 27,00 & 27,66 & 27,66 \\
$\mathrm{pH}$ & 7,53 & 7,60 & 7,56 \\
Salinitas (ppt) & 24,66 & 25,00 & 25,00 \\
\hline
\end{tabular}

Berdasarkan hasil pengukuran kualitas perairan pada Tabel 1 dapat diketahui bahwa nilai rata-rata suhu, salinitas dan $\mathrm{pH}$ di lokasi tersebut antar transek relatif sama atau tidak jauh berbeda dan masih berada dalam kisaran yang baik bagi pertumbuhan mangrove. Kualitas perairan yang relatif sama disebabkan tidak faktor yang menyebabkan berbedanya seperti adanya sungai yang bermuara ke kawasan tersebut yang dapat mempengaruhi suhu, $\mathrm{pH}$ dan salinitas. Kualitas perairan berupa suhu, salinitas dan $\mathrm{pH}$ di kawasan mangrove rehabilitasi Desa Kedaburapat berada dalam kisaran yang dapat mendukung kehidupan mangrove dan biota lainnya. Menurut Ulqodry et al. (2010) bahwa suhu yang baik untuk tumbuh mangrove adalah tidak kurang dari $20^{\circ} \mathrm{C}$. Vegetasi mangrove tumbuh dengan baik pada salinitas 10-30 ppt (Wantasen, 2013). Parameter lingkungan yang diukur menunjukkan bahwa kawasan rehabilitasi mangrove di Kedaburapatini dapat mendukung kehidupan Gastropoda dengan baik. Menurut Dharma (1988), gastropoda memiliki kemampuan beradaptasi terhadap suhu yang baik.

\section{Tipe Sedimen Kawasan Rehabilitasi}

Hasil analisis fraksi sedimen pada setiap zona di kawasan rehabilitasi mangrove Desa Kedaburapat diperoleh tipe sedimen seperti pada Tabel 2.

Tabel 2. Tipe sedimen pada kawasan mangrove rehabilitasi Desa Kedaburapat

\begin{tabular}{lcccl}
\hline Zona & $\begin{array}{c}\text { Fraksi kerikil } \\
(\%)\end{array}$ & $\begin{array}{c}\text { Fraksi pasir } \\
(\%)\end{array}$ & $\begin{array}{c}\text { Fraksi lumpur } \\
(\%)\end{array}$ & Tipe sedimen \\
\hline Upper & 3.00 & 37,17 & 59,83 & Lumpur berpasir \\
Middle & 2,67 & 45,60 & 51,73 & Lumpur berpasir \\
Lower & 2,25 & 52,51 & 45,24 & Pasir berlumpur \\
\hline
\end{tabular}

Pada Tabel 2 dapat diketahui bahwa tipe sedimen di upper dan middle mempunyai tipe sedimen lumpur berpasir, sementara zona lower yang berhadapan dengan pemecah gelombang mempunyai tipe sedimen berbeda, yaitu pasir berlumpur. Substrat pasir berlumpur yang ditemukan di zona lower dikarenakan keberadaan batu pemecah gelombang yang ada di zona lower terebut. Keberadaan pemecah gelombang ini telah memberikan kesempatan material tersuspensi mengendap karena arus yang melemah termasuk material tersuspnesi yan berukuran besar seperti pasir. Substrat lumpur berpasir ini sangat cocok bagi pertumbuhan
Avicennia yang ditanam di kawasan rehabilitasi ini. Onrizal \& Kusmana (2004) menyatakan bahwa bahwa Rhizophora tumbuh baik pada substrat berlumpur halus, sedangkan Avicennia menyukai substrat campuran lumpur dan pasir.

\section{Kandungan Nitrat dan Fosfat Pada Air dan Sedimen di Kawasan Rehabilitasi Mangrove \\ Rata-rata kandungan nitrat dan fosfat pada air dan sedimen di kawasan rehabilitasi mangrove Kedaburapat dapat dilihat seperti pada Tabel 3.}


Tabe1 3. Kandungan Nitrat dan Fosfat pada Sedimen dan Air di Kawasan Mangrove Rehabilitasi

\begin{tabular}{ccccc}
\hline Zona & \multicolumn{3}{c}{ Sedimen } & \multicolumn{2}{c}{ Air } \\
\cline { 2 - 5 } Upper & Nitrat (mg/l) & Fosfat (mg/l) & Nitrat (mg/l) & Fosfat (mg/l) \\
Middle & 0,0298 & 0,1430 & 0,0958 & 0,1571 \\
Lower & 0,0194 & 0,1202 & 0,1167 & 0,1836 \\
Rata-rata & 0,0367 & 0,1002 & 0,0958 & 0,1593 \\
& 0,0286 & 0,1211 & 0,1027 & 0,1667 \\
\hline
\end{tabular}

Berdasarkan Tabel 3 dapat diketahui bahwa kandungan nitrat dan fosfat pada sedimen dan air antar zona tidak menunjukkan perbedaan yang besar dan tidak ada kecenderungannya. Rata-rata kandungan nitrat dan fosfat pada sedimen secara berturut-turat adalah $0,0286 \mathrm{mg} / 1 \mathrm{dan} 0,1211 \mathrm{mg} / 1$. Pada air, rata-rata kandungan nitrat dan fosfat $0,1211 \mathrm{mg} / 1$ dan $0,1667 \mathrm{mg} / 1$ secara berturut-turut. Kandungan nitrat sedimen di kawasan mangrove rehabilitasi ini relatif rendah. Hal ini dikarenakan sumbangan dari serasah api-api yang masih kecil masih sedikit serta tidak ada masukan dari daratan melalui sungai. Menurut Permatasari et al. (2019) bahwa kandungan fosfat dalam tanah dapat dibagi 4 (empat) yaitu $<3 \mathrm{mg} / \mathrm{kg}$ : sangat rendah, $3-7 \mathrm{mg} / \mathrm{kg}$ : rendah, $7-20 \mathrm{mg} / \mathrm{kg}$ : sedang, dan $>20 \mathrm{mg} / \mathrm{kg}$ : tinggi. Yahra (2020) menyatakan bahwa kandungan nitrat sedimen yang diperolehnya sebesar $0,27 \mathrm{mg} / \mathrm{kg}$ tergolong rendah. Kandungan nitrat pada sedimen yang rendah memiliki pengaruh terhadap mangrove. Hartoko et al. (2013) menyatakan bahwa nutrien utama yang menentukan kestabilan pertumbuhan vegetasi adalah nitrat $\left(\mathrm{NO}_{3}\right)$ dan fosfat $\left(\mathrm{PO}_{4}\right)$. Kandungan nitrat dan fosfat di sedimen juga dipengaruhi tipe sedimen. Mahmud et al. (2014) menyatakan bahwa tanah dengan tekstur pasir mempunyai luas permukaan yang kecil dibandingkan tekstur lumpur yang lebih halus, sehingga sulit untuk menahan air dan nutrien.

\section{Pertumbuhan Avicennia alba}

Hasil analisis pertumbuhan tinggi dan diameter Avicennia alba setiap zona yang dilakukan setiap bulan selama 3 bulan sejak bulan Juli hingga Oktober tahun 2020 dapat diperoleh nilai seperti pada Gambar 3 dan 4.

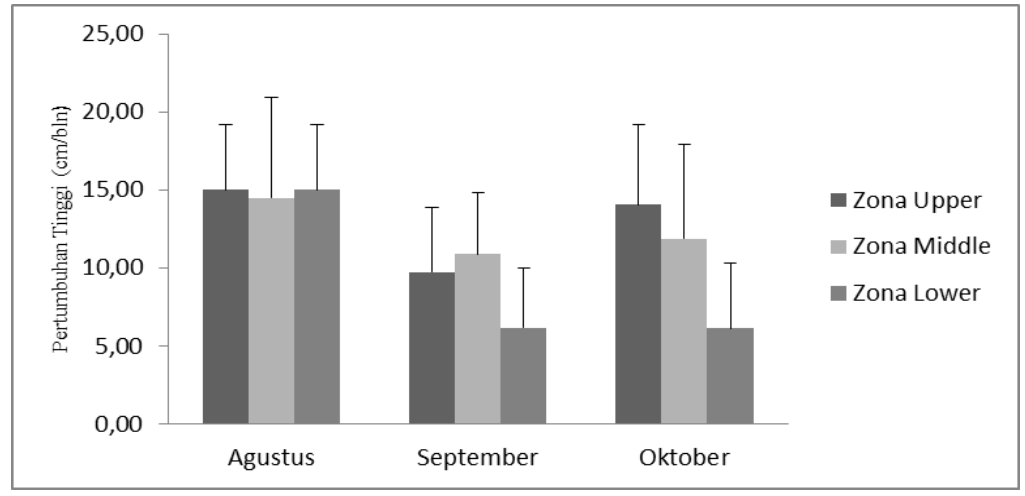

Gambar 3. Pertumbuhan rata-rata tinggi anakan $A$. alba per zona setiap bulan

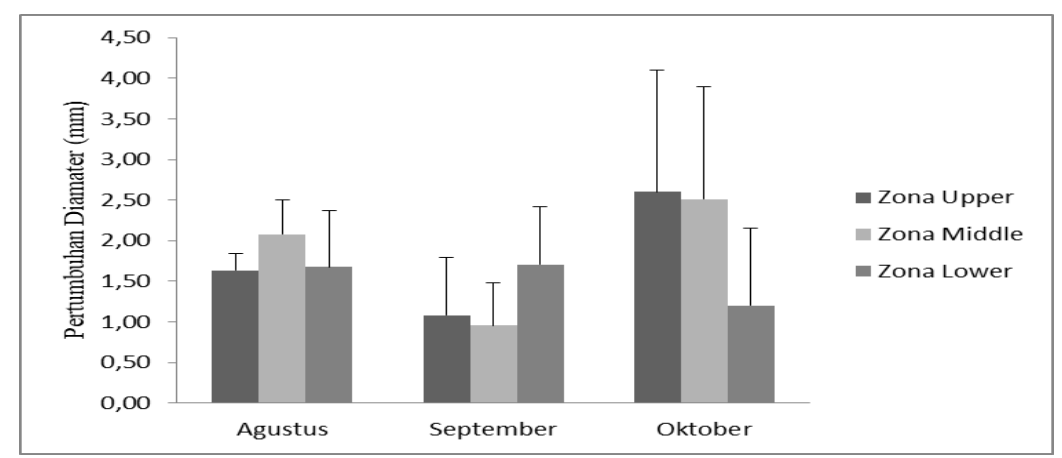

Gambar 4. Pertumbuhan rata-rata diameter batang anakan A. alba setiap zona per bulan 
Gambar 3 dan 4 menunjukkan bahwa tidak sama pertumbuhan tinggi dan diameter anakan api-api pada setiap bulan pengamatan. Perkembangan pertumbuhan tinggi dan diameter pohon Avicennia alba yang ditanam pada tahun 2019 (satu tahun setelah tahun penanaman) tidak sama setiap bulannya. Pertumbuhan tinggi dan diameter batang rata-rata anakan api-api mengalami penurunan pada Bulan September karena pada bulan tersebut merupakan musim hujan dengan angin yang relatif kuat yang dapat mempengaruhi pertumbuhannya. Menurut Ghufron et al. (2015) bahwa angin yang kuat memungkinkan terganggunya pertumbuhan mangrove karena menyebabkan tidak normalnya karakteristik fisiologis. Aksi gelombang dan arus yang kuat di perairan pantai yang ditimbulkan oleh angin akan memberikan pengaruh terhadap ekosistem mangrove.

Perkembangan tinggi dan diameter pohon tidak sama pada setiap zona tanam menunjukkan zona penanaman memberikan pengaruh yang berbeda terhadap perkembangan Avicennia yang ditanam. Hasil perhitungan rata-rata pertumbuhan tinggi dan diameter per bulan setiap zona yang dilakukan selama 3 bulan pengukuran sejak bulan Juli hingga Oktober tahun 2020 dapat diperoleh nilai seperti pada Gambar 5 dan 6.

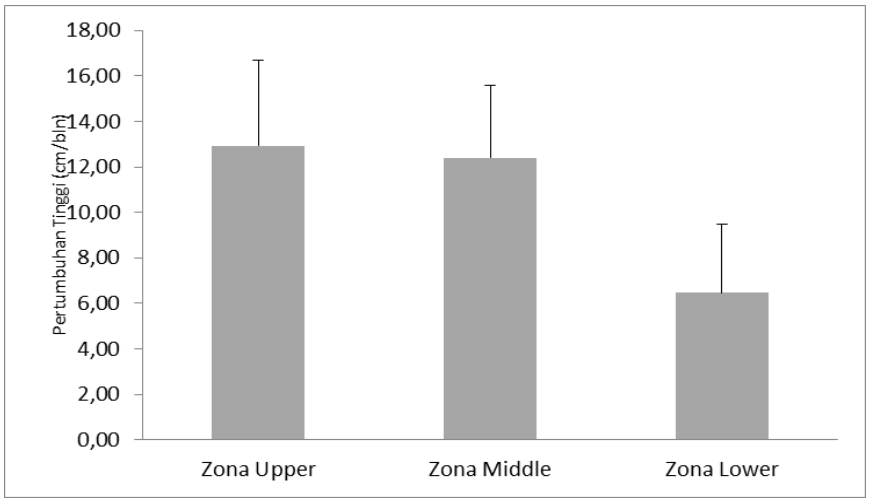

Gambar 5. Pertumbuhan tinggi rata-rata anakan A. alba setiap zona per bulan

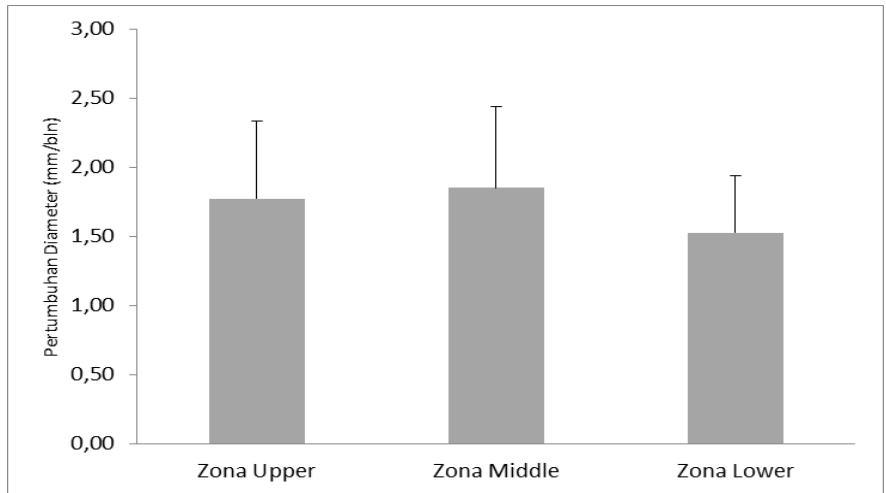

Gambar 6. Pertumbuhan diameter anakan $A$. alba setiap zona per bulan

Rata-rata nilai pertumbuhan tinggi batang berdasarkan zona berkisar antara $6,45-12,93 \mathrm{~cm} / \mathrm{bln}$. Rata-rata nilai pertumbuhan diameter batang api-api berdasarkan zona adalah 1,53-1,85 mm/bln. Hasil pengukuran menjukkan bahwa nilai rata-rata pertumbuhan tinggi batang api-api tertinggi diperoleh pada zona upper, sedangkan nilai rata-rata pertumbuhan tinggi batang terendah pada zona lower. Rata-rata pertambahan diameter batang, tertinggi juga terdapat pada zona middle dan terendah pada zona lower. Hasil analisis Uji Anova memperlihatkan adanya perbedaan yang nyata antar zona rata-rata pertumbuhan tinggi per bulannya. Pertambahan tinggi batang anakan antara zona upper dan lower serta zona middle dan lower menunjukkan perbedaan yang nyata, namun tidak demikian halnya antara zona upper dan zona middle. Sementara itu pertumbuhan diameter batang anakan api-api tidak menunjukkan perbedaan yang nyata antar zona. Aktivitas jaringan meristem yakni meristem lateral akan mempengaruhi pertumbuhan diameter anakan api-api. Meristem lateral yang disebut juga dengan meristem samping merupakan meristem yang menyebabkan pertumbuhan ke arah samping atau membesar. Aktivitas jaringan meristem lateral menyebabkan pertambahan diameter tumbuhan.

Kondisi lingkungan yang menjadi tempat tumbuhnya sangat mempengaruhi pertumbuhan 
diameter anakan A. alba. Latifah (2004) menyatakan bahwa pertumbuhan diameter batang terjadi apabila hasil fotosintesis untuk keperluan respirasi, pertumbuhan akar dan tinggi telah terpenuhi. Menurut Anwar (2007) bahwa tingkat penggenangan berpengaruh nyata terhadap diameter batang anakan untuk A. marina.

Salinitas yang tinggi dapat mengganggu aktivitas dari meristem lateral. Harjadi (1993) menyatakan bahwa perkembangan sel baru, pemanjangan dan penebalan dinding sel akan menentukan diameter. Proses-proses tersebut sangat membutuhkan karbohidrat dan air bagi pembesaran vakuola-vakuola pada semua bagian yang sedang mengalami pertumbuhan.

Penelitian yang dilakukan Santoso et al. (2007) di Muara Angke diperoleh pertumbuhan tinggi ratarata pidada (Sonneratia sp) sebesar 18,5 - $42 \mathrm{~cm} / \mathrm{bln}$ Pertumbuhan tinggi pidada dipengaruhi oleh kedalaman lumpur dan tahun tanam. Pertumbuhan tinggi pidada pada kondisi lingkungan yang tergenang atau terkena pasang surut lebih besar $(41,8 \mathrm{~cm} /$ bulan $)$ dibandingkan pada kondisi lingkungan yang jarang/tidak tergenang $(29,2 \mathrm{~cm} /$ bulan $)$. Selanjutnya Aksornkoae (1993) memperoleh pertumbuhan tinggi Sonneratia ovata hutan alam pada pohon berdiameter $34,1 \mathrm{~cm}$ sekitar $0,56 \mathrm{~cm} /$ tahun di Ranong-Thailand

Santoso et al. (2007) memperoleh pertumbuhan diameter mangrove pidada di Muara
Angke berkisar antara 1,75-3,45 cm/bulan. Pertumbuhan diameter pidada pada tanaman umur 4 tahun (lebih tinggi $(3,45 \mathrm{~cm} /$ bulan) dibandingkan dengan tanaman umur 2 tahun sebesar 1,75-2,83 $\mathrm{cm} /$ bulan dan umur 1 tahun (tahun tanam 2003) sebesar 2,4 cm/bulan. Kondisi lingkungan yang tergenang dan kedalaman lumpur berpengaruh terhadap pertumbuhan diameter. Kedalaman lumpur yang dangkal memberikan pertumbuhan diameter paling tinggi.

Perbedaan tinggi suatu tanaman dapat disebabkan oleh banyak faktor seperti pertumbuhan yang tidak normal, yaitu dimana terdapat beberapa tanaman yang tumbuhnya kecil atau kerdil, tanaman yang diserang oleh hama dan penyakit yang menyebabkan rontoknya daun sehingga pertumbuhan vegetasi terganggu, dan penanaman jenis tanaman tidak sesuai dengan zona tumbuh yang baiknya.

\section{Spesies dan Kelimpahan Epifauna bentik}

Epifauna bentik yang didapatkan pada kawasan rehabilitasi mangrove Desa Kedaburapat adalah 13 spesies dari 9 famili dan 2 kelas, yaitu kelas gastropoda dan malacostrata dengan kelimpahan yang tidak sama setiap zona seperti halnya yang dapat dilihat pada Tabel 4 .

Tabel 4. Spesies dan kelimpahan rata-rata epifauna bentik yang ditemukan di mangrove rehabilitasi Desa Kedaburapat

\begin{tabular}{llccc}
\hline Kelas/Famili & Spesies & \multicolumn{3}{c}{ Kelimpahan rata-rata (ind $/ \mathrm{m}^{2}$ ) } \\
\cline { 3 - 5 } Gastropoda & & 1 (Upper) & 2 (Middle) & 3 (Lower) \\
Littorinidae & Littoraria scabra & 4,22 & 3,78 & 0,56 \\
& L. melanostoma & 15,11 & 10,44 & 4,67 \\
& L. intermedia & 2,11 & 7,89 & 9,89 \\
& L. lutea & 0,22 & 0,78 & 1,33 \\
Assimineidae & Sphaerassiminea miniata & 1,67 & 26,22 & 29,33 \\
Nassariidae & Nassarius dorsatus & 0,44 & 0,44 & 2,56 \\
& Nassa olivacea & 0,00 & 0,00 & 0,22 \\
Potamididae & Cerithidea cingulata & 6,00 & 0,00 & 0,00 \\
Melonginidae & Volema myristica & 0,89 & 1,33 & 2,44 \\
Malacostraca & & & & \\
Ocypodidae & Uca coarctata & 0,33 & 0,00 & 0,11 \\
Grapsidae & Metopograpsus latifrons & 0,22 & 0,00 & 0,00 \\
Ceonobitidae & Ceonobita cavipes & 0,00 & 0,00 & 0,11 \\
Diogenidae & Clibanarius longitarsus & 0,11 & 0,44 & 0,00 \\
Total & & 31,33 & 52,22 & 51,33 \\
Jumlah spesies & & 11 & 8 & 10 \\
\hline
\end{tabular}


Pada Tabel 4 juga dapat dilihat bahwa jumlah spesies epifauna bentik lebih banyak dari kelas gastropoda, demikian juga kelimpahan yang tinggi juga spesies dari kelas gastropoda seperti Littoraria melanostoma dan Sphaerassiminea miniata. Jumlah spesies dan kelimpahaan pada setiap zona tidak sama. Namun demikian hasil uji Anova diperoleh bahwa kelimpahan antar zona tidak menunjukkan perbedaan yang nyata dengan nilai sig. 0,370>0,05.

Tingginya jumlah spesies dari kelas gastropoda diduga karena tipe substrat pada ketiga zona yang didominasi oleh pasir berlumpur. Menurut Syamsurial (2011), gastropoda cenderung memilih substrat pasir berlumpur karena memudahkannya untuk bergeser dan bergerak ke tempat lain. Sementara Febrita et al. (2015) menyatakan bahwa substrat lumpur sangat disukai oleh gastropoda karena teksturnya halus dan memiliki kadar bahan organik yang lebih tinggi dari pada substrat yang bertekstur kasar. Bahan organik lebih muda mengendap di partikel yang halus sehingga sangat baik bagi kelangsungan hidup gastropoda. Azham et al. (2016) menyatakan bahwa gastropoda memiliki adaptasi yang baik dengan cangkang yang keras, sehingga lebih memungkinkan untuk bertahan hidup pada lingkungan yang berflutuasi. Selanjutnya Taqwa (2010), menyatakan bahwa besarnya persentase gastropoda di ekosistem mangrove karena jenisnya yang paling banyak dan pergerakannya yang lambat, sehingga sangat mudah untuk ditemukan di hutan mangrove.

Jumlah jenis gastropoda di kawasan rehabilitasi mangrove Desa' Kedaburapat ini lebih sedikit jika dibandingkan dengan yang diperoleh Omar et al. (2012) \& Ernawati et al. (2013) di ekosistem mangrove rehabilitasi yang terdapat di Tongke-tongke yaitu sebanyak 22 spesies dari 11 famili. Hal ini dikarenakan mangrove di Desa Kedaburapat relatif muda atau masih relatif kecil dengan umur satu tahun. Selain itu juga karena keberadaan kawasan mangrove hasil rehabilitasi di Desa Kedaburapat ini jauh dari hutan mangrove alami sebagai sumber larva yang akan menyebar ke kawasan mangrove rehabilitasi ini.

Littoraria melanostoma merupakan jenis yang mempunyai kelimpahan yang tinggi pada pada semua zona. Jenis ini merupakan gastropoda yang mendiami pohon mangrove, baik pada batang, cabang maupun daunnya. Kelimpahan gastropoda di Kedaburapat ini lebih rendah. Hal ini diduga karena belum punya banyak waktu bagi biota yang hidup di kawasan mangrove rehabilitasi yang relatif baru untuk berkembang biak. Gastropoda di kawasan mangrove Desa Kedaburapat mempunyai kelimpahan yang lebih lebih rendah dibandingkan gastropoda di Segara Anakan yang mencapai 58,2 ind./m2 (Pribadi et al., 2009). Selain L. melanostoma, jenis L. scabra juga didapatkan relatif melimpah, namun lebih rendah dibandingkan yang diperoleh Syahrial et al. (2018) di mangrove reboisasi Kepulauan Seribu yaitu 6,33-18,80 ind/m2. Menurut
Saru (2013), spesies yang menyebar secara vertikal pada ekosistem mangrove adalah Littorina scrabra, Littorina melanostoma, Cerithidea sp. dan Clibanarius longitarsus. Famili yang paling banyak ditemukan yaitu Littorinidae. Ini menunjukkan bahwa famili ini mudah beradaptasi atau memiliki adaptasi yang tinggi terhadap kondisi kualitas perairan di kawasan mangrove ini. Rangkuti et al. (2017) memperoleh hasil bahwa Littorina sp. dan Nerita sp. adalah spesies gastropoda yang banyak dijumpai berasosiasi dengan mangrove. Distribusi vertikal dari spesies Littorina sp dipengaruhi oleh sumber makanan, siklus pasang air laut, reproduksi dan agregasi pada saat distribusi (Alfaro, 2007). Spesies Littorina sp dapat ditemukan di mangrove ukuran kecil sampai dengan tinggi (Tanaka \& Maia, 2006). Elviana dan Lantang (2016) menyatakan bahwa famili Littorinidae adalah gastropoda asli penghuni hutan mangrove yang memiliki toleransi yang tinggi terhadap fluktuasi parameter lingkungan yang terjadi. Tuheteru et al. (2014), menyebutkan bahwa pada saat air surut ada beberapa gastropoda yang hidup menempel pada akar mangove dengan substrat berlumpur untuk menghindar dari hewan yang memangsanya, seperti biawak, babi, dan burung.

Perbedaan kelimpahan epifauna bentik antar zona yang tidak nyata disebabkan kondisi lingkungan yang relatif sama dalam kawasan mangrove tersebut. Keberadaan pemecah ombak bagian ke laut diperkirakan juga menyebabkan kawasan mangrove seolah-olah mempunyai dua sisi darat, sehingga terjangan gelombang laut tidak ada. Selanjutnya tidak ada perbedaan epifauna antar zona diduga juga karena jarak tanam anakan api-api sebagai tempat menempel sebagian besar epifauna bentik yang sama yaitu $1 \mathrm{~m} \mathrm{x} 1$ m. Epifauna bentik yang didapat relatif lebih banyak berada menempel pada anakan api-api tersebut, baik di batang, di ranting, atau di daun. Menurut Tomlinson (1994) bahwa lingkungan mangrove sebagai mikro habitat dari berbagai fauna meliputi di bawah kanopi, di akar, di batang, di cabang, di atas dan di bawah permukaan tanah, serta di dalam dan di luar genangan air. Tomascik et al. (1997) menyatakan bahwa Littorina melanostoma menempel pada batang pohon di atas batas air pasang tinggi, sementara L. scabra terlihat memilih substrat daun, sehingga sering kali ditemukan menempel pada daun.

\section{SIMPULAN}

Pertumbuhan tinggi dan diameter anakan apiapi mengalami penurunan pada bulan September. Ratarata nilai pertumbuhan tinggi anakan api-api pada kawasan mangrove rehabilitasi Desa Kedaburapat berkisar 6,45-12,93 $\mathrm{cm} / \mathrm{bln}$ dan rata-rata nilai pertumbuhan diameter batang berkisar antara 1,53-1,85 $\mathrm{mm} / \mathrm{bln}$. 
Ditemukan sebanyak 13 jenis epifauna bentik di mangrove rehabilitasi Desa Kedaburapat. Gastropoda merupakan spesies dengan jumlah spesies yang banyak, terutama dari genus Littoraria. Kelimpahan epifauna bentik antar zona dalam kawasan mangrove rehabilitasi tidak berbeda nyata.

\section{UCAPAN TERIMA KASIH}

Terima kasih disampaikan kepada Lembaga Penelitian dan Pengabdian kepada Masyarakat Universitas Riau yang telah mendanai penelitian ini melalui DIPA Tahun 2020 dan kepada Bapak Warsiman selaku ketua POKMASWAS Karya Pesisir Desa Kedaburapat yang telah menfasilitasi penelitian ini, khususnya selama di lapangan.

\section{DAFTAR PUSTAKA}

Aksornkoae, S. (1993). Ecology \& Management of Mangroves. The International Union of Nature \& Natural Resources (IUCN) Wetlands Programme. Bangkok, Thailand. $79 \mathrm{p}$.

Alfaro, A.C. (2007). Migration \& trail affinity of snails, Littoraria scabra, on mangrove trees of Nananuria, Fiji Islands. Marine and Freshwater behaviour and Physiology, 40(40): 247-255.

Anwar, C. (2007). Pertumbuhan Anakan Mangrove Pada Berbagai Jarak Tanam dan Tingkat Penggenangan Air Laut di Pemalang, Jawa Tengah. Jurnal Penelitian Hutan Konservasi Alam, 4(4): 253-364. https://doi.org/10.20886/jphka.2007.4.4.353-364.

Azham, R.S., Bahtiar \& Ketjulan, R. (2016). Struktur Komunitas Makrozoobenthos Pada Ekosistem Mangrove di Perairan Teluk Staring Kabupaten Konawe Selatan. Jurnal Manajemen Sumber Daya Perairan, 1(3): 249-260.

Bengen, D.G. (2002). Pedoman Teknis Pengenalan dan Pengelolaan Ekosistem Mangrove. Pusat Kajian Sumberdaya Pesisir dan Lautan. Institut Pertanian Bogor. Bogor, Indonesia. 56 halaman.

Dharma, B. (1988). Siput dan Kerang Indonesia I. PT. Sarana Graha. Jakarta. 111 Halaman.

Elviana, S \& Lantang, B. (2016). Inventarisasi gastropoda pada ekosistem mangrove di perairan pantai Payumb, Kabupaten Merauke. Agricola: Jurnal Pertanian Universitas Musamus, 6(1): 40-45.

Ernawati, E. Suprayitno, Hardoko \& Yanuhar, U. (2018). Kajian Pencemaran Ekosistem Mangrove Jenis Rhizophora mucronata di Perairan Desa Kalianyar Bangil Pasuruan Jawa Timur. Jurnal IlmuIlmu Pertanian Agrika, 12(1): 61-72. https://doi.org/10.31328/ja.v12i1.545

Febrita, E., Darmawati., \& Astuti, J. (2015). Keanekaragaman Gastropoda dan Bivalvia Hutan Mangrove Sebagai Media Pembelajaran Pada Konsep
Keanekaragaman Hayati Kelas X SMA. Jurnal Biogenesis 11(2):119-128.

Ghufron, R. R., Kusmana, C., \& Rusdian, O. (2015). Komposisi Jenis Dan Struktur Hutan Mangrove di Pulau Sebuku, Kalimantan Selatan. Jurnal Silvikultur Tropika, 6(1): 15-26.

Harjadi, S.S. (1993). Pengantar Agronomi. Gramedia Pustaka Utama. 197 hal.

Hartoko, A., P. Soedarsono \& Indrawati, A. (2013). Analisa Klorofil-a, Nitrat dan Fosfat pada Vegetasi Mangrove Berdasarkan Data Lapangan dan Satelit Geoeye di Pulau Parang, Kepulauan Karimunjawa. Journal of Management of Aquatic Resources. 2 (2): 28-37.

Kusmana, C., Onrizal, \& Sudarmaji. (2003). Jenis-Jenis Pohon Mangrove di Teluk. Bintuni Papua. Bogor : Fakultas Kehutanan Institut Pertanian Bogor. 58 halaman.

Latifah, S. (2004). Pertumbuhan dan Hasil Tegakan Eucalyptus grandis di Hutan Tanaman Industri. Universitas Sumatera Utara. Medan. 11 hal.

Mahmud., Wardah \& Toknok, B. (2014). Sifat Fisik Tanah di Bawah Tegakan Mangrove di Desa Tumpapa Kecamatan Balinggi Kabupaten Parigi Moutong. Warta Rimba. 2 (1): 129-135.

Morton, J. (1990). The Shore Ecology of The Tropical Pacific 1st Edition. UNESCO. Jakarta. 90 p.

Omar, A. S., R. Sirante, Suwarni \& Litaay, M. (2012). Keanekaragaman Gastropoda (Moluska) di Ekosistem Mangrove Kabupaten Sinjai, Sulawesi Selatan. Makalah disajikan pada Seminar Nasional Moluska III. Makassar, 14 Juni.

Onrizal \& C. Kusmana. (2004). Ekologi dan Manajemen Mangrove. Buku Ajar. Jurusan Kehutanan Fakultas Pertanian, Universitas Sumatera Utara.

Permatasari, I.R., B.S. Barus \& G. Diansyah, G. (2019). Analisis Nitrat dan Fosfat Sedimen di Muara Sungai Banyuasin, Kabupaten Banyuasin, Sumatera Selatan. Jurnal Penelitian Sains. 21 (3): 140-150. https://doi.org/10.26554/jps.v21i3.545

Pribadi, R., R. Hartati, C. A. Suryono. (2009). Komposisi spesies dan penyebaran gastrpoda di hutan mangrove Segara Anakan Cilacap, Jurnal Ilmu Kelautan, 14(2) : 102-111. https://doi.org/10.14710/ik.ijms.14.2.102-111.

Rangkuti, A. M., M. R. Cardova, A. Rahmawati, Yulma \& H. E. Adimu, H.E. (2017). Ekosistem Pesisir dan Laut Indonesia. Bumi Aksara. Jakarta. 482 halaman.

Santoso N, Kusmana C, Sudarmana D, Sukmadi R. (2007). Ekologi Tumbuhan Pidada (Sonneratia caseolaris (L) Engler 1897 pada Kawasan Muara Angke Propinsi Daerah Khusus Ibukota Jakarta. IPB, Bogor.

Saru, A. (2013). Mengungkap Potensi Emas Hijau di Wilayah Pesisir. Masagena Press, Makassar. 238 halaman. 
Susila, I.W.W. (2010). Riap tegakan duabanga (Duabanga moluccana B1.) di Rarung. Jurnal Penelitian dan Konservasi Alam, 7(1):47-58. https://doi.org/10.20886/jphka.2010.7.1.47-58

Susetiono. (2005). Krustasea dan Moluska Mangrove Delta Mahakam. Pusat Penelitian Oseanografi-LIPI. Jakarta. 72 halaman.

Syahrial, C.E. Larasati, D. Saleky, H. Susilo, R. Wahyudi. (2018). Biota Asosiasi Pada Kawasan Reboisasi Mangrove Kepulauan Seribu. Journal of Aceh Aquatic Science, 2(1): 48-62. https://doi.org/10.35308/.v2i1.1688

Syamsurial. (2011). Studi Beberapa Indeks Komunitas Makrozoobentos di Hutan Mangrove Kelurahan Coppo Kabupaten Baru. [Skripsi]. Program Studi Perikanan Fakultas Ilmu Kelautan dan Perikanan Universitas Hasanudin. Makassar. 57 Halaman.

Tanaka, M. O., \& Maia, R.C. (2006). Shell Morphological Variation of Littoraria angulifera Among and Within Mangroves in NE Brazil. Hydrobiologia, 559: 193-202.

Taqwa, A. (2010). Analisis Produktivitas Primer Fitoplankton dan Struktur Komunitas Fauna Makrobenthos Berdasarkan Kerapatan Mangrove di Kawasan Konservasi Mangrove dan Bekantan Kota Tarakan, Kalimantan Timur. [Tesis]. Program Pasca Sarjana Universitas Diponegoro, Semarang.
Tomascik, T, Mah A.J, Nontji A, Moosa MK. (1997). The Ecology of Indonesian Seas. Part II. Periplus Editions, Singapore. 933 p.

Tomlinson, PB. (1994). The Botany of Mangrove. Cambridge University Press, Cambridge. 419 p.

Tuheteru, M., S. Notosoedarmo, \& Martosupono, M. (2014). Distribusi Gastropoda di Ekosistem Mangrove. Prosiding Seminar Nasional Raja Ampat. Waisai, 12 - 13 Agustus.

Ulqodry, T. Z., Yulisman, M. Syahdan \& Santoso. (2010). Karateristik dan Sebaran Nitrat, Fosfat, dan Oksigen Terlarut di Perairan Karimunjawa Jawa Tengah. Jurnal Penelitian Sains, 13 (1): 35-41. https://doi.org/10.26554/jps.v13i1.162

Wantasen, A. S. (2014). Conditions of Substrate and Water Quality Supporting Activites as a Growth Factor in Mangrove at Coastal Basaan I, South East District Minahasa. Jurnal Ilmiah Platax, 1(4): 204-209. https://doi.org/10.35800/jip.1.4.2013.3704

Yahra, S. (2020). Analisis Kandungan Nitrat dan Fosfat Serta Keterkaitannya Dengan Kerapatan Mangrove di Pantai Labu Kabupaten Deli Serdang. [Skripsi]. Program Studi Manajemen Sumberdaya Perairan Fakultas Pertanian Universitas Sumatera Utara, Medan. 79 Halaman. 